\title{
Association between three exonuclease I polymorphisms and cancer risks: a meta-analysis
}

\author{
This article was published in the following Dove Press journal: \\ OncoTargets and Therapy \\ 23 February 2016 \\ Number of times this article has been viewed
}

\author{
Zi-Yu Chen ${ }^{1,2}$ \\ Si-Rong Zheng ${ }^{2}$ \\ Jie-Hui Zhong ${ }^{1,2}$ \\ Xiao-Duan Zhuang ${ }^{1,2}$ \\ Jue-Yu Zhou² \\ 'Department of Clinical Medicine, \\ The First Clinical Medical College, \\ Southern Medical University, ${ }^{2}$ Institute \\ of Genetic Engineering, School of \\ Basic Medical Sciences, Southern \\ Medical University, Guangzhou, \\ People's Republic of China
}

\begin{abstract}
To date, the results of studies exploring the relation between exonuclease 1 (Exo1) polymorphisms and cancer risks have differed. In this study, we performed a meta-analysis to investigate the effect of the three most extensively studied Exo1 polymorphisms (Pro757Leu, Glu589Lys, and Glu670Gly) on cancer susceptibility. The related studies published before August 5, 2015, were collected by searching the PubMed and EMBASE databases. We found 16 publications containing studies that were eligible for our study, including 10 studies for Pro757Leu polymorphism (4,093 cases and 3,834 controls), 12 studies for Glu589Lys polymorphism (6,479 cases and 6,550 controls), and 7 studies for Glu670Gly polymorphism (3,700 cases and 3,496 controls). Pooled odds ratios and 95\% confidence intervals were used to assess the strength of the associations, and all the statistical analyses were calculated using the software program STATA version 12.0. Our results revealed that the Pro757Leu polymorphism was significantly associated with a reduced cancer risk, whereas an inverse association was found for the Glu589Lys polymorphism. Furthermore, subgroup analysis of smoking status indicated that the Glu589Lys polymorphism was significantly associated with an increased cancer risk in smokers, but not in nonsmokers. However, no evidence was found for an association between the Glu670Gly polymorphism and cancer risk. In conclusion, this meta-analysis suggests that the Pro757Leu polymorphism may provide protective effects against cancer, while the Glu589Lys polymorphism may be a risk factor for cancer. Moreover, the Glu670Gly polymorphism may have no influence on cancer susceptibility. In the future, large-scaled and well-designed studies are needed to achieve a more precise and comprehensive result.
\end{abstract}

Keywords: exonuclease 1, polymorphism, cancer risks, meta-analysis

\section{Introduction}

Cancer, caused by complex factors including genetics and environment, as well as by the interactions between these two factors, is a severe global public-health problem. ${ }^{1,2}$ DNA damage may lead to human cancer, while DNA repair pathways such as mismatch repair (MMR) in mammals may play a role in repairing such damage. ${ }^{3,4}$ Genetic variations in DNA repair genes may influence repair efficiency and alter cancer risks. ${ }^{5}$

The exonuclease 1 (Exol) gene, belonging to the MMR system and the RAD2/XPG nuclease family, encodes an 846 amino acid protein, which functions in DNA repair, replication, and homologous recombination. ${ }^{6-9}$ Exol can interact physically with the MMR proteins MLH1 and MSH2 and participate in mismatch-provoked excision repair by forming a ternary complex of Exo1-MLH1-PMS2 or Exo1-MSH2-MSH6. ${ }^{10-12}$

Several nonsynonymous coding polymorphisms in the Exol gene have been identified. These polymorphisms may lead to amino acid changes and may affect the interactions between the Exo1 protein and other MMR proteins, resulting in altered DNA repair capacity and influencing cancer risks. ${ }^{13,14}$ In consideration of the possible
Correspondence: Jue-Yu Zhou Institute of Genetic Engineering, 7th Floor, Life Science Building, Southern Medical University, 1838 North

Guangzhou Avenue, Guangzhou 5105I5, People's Republic of China

Tel +862061648209

Email zhoujueyu@I26.com
OncoTargets and Therapy 2016:9 899-910

Dovepress

http://dx.doi.org/10.2147/OTT.S95258 (c) (i) (5) 2016 Chen et al. This work is published and licensed by Dove Medical Press Limited. The full terms of this license are available at https://www.dovepress.com/terms.php cC. hereby accept the Terms. Non-commercial uses of the work are permitted without any further permission from Dove Medical Press Limited, provided the work is properly attributed. For permission for commercial use of this work, please see paragraphs 4.2 and 5 of our Terms (https://www.dovepress.com/terms.php). 
influence of the genetic variants on the repair efficiency of the MMR system and cancer susceptibilities, many studies have assessed the relationship between Exol polymorphisms and cancer risks.

To date, three single-nucleotide polymorphisms (SNPs) of the Exo1 gene - Pro757Leu (rs9350, C/T) at exon 13, Glu589Lys (rs1047840, G/A), and Glu670Gly (rs1776148, A/G) at exon 11 - have been the most widely investigated in epidemiological studies. ${ }^{15-30}$ Not all of these studies, however, reached the same conclusion, which may be partly due to the limitations of individual studies. Therefore, we carried out this meta-analysis of all eligible case-control studies to draw a more reliable conclusion of the association between Exo1 polymorphisms (Glu589Lys, Pro757Leu, and Glu670Gly) and cancer susceptibility.

\section{Materials and methods}

\section{Study identification and inclusion criteria}

We searched the PubMed and EMBASE databases for relevant studies (last search was updated on August 5, 2015). Without applying search filters, the following keywords were used for the literature search: (Exo1 or "Exonuclease 1"), (cancer or carcinoma or tumor or neoplasm), and (polymorphism or variant or variation or mutation). Furthermore, the references in the retrieved articles were also manually screened to ensure that no relevant publication was missed.

All studies used in our meta-analysis were carefully examined to meet the following criteria: case-control studies conducted on human subjects, with full text articles that investigated the association between cancer risk and at least one of three Exol gene polymorphisms (Pro757Leu, Glu589Lys, or Glu670Gly). Another requirement of these studies was the inclusion of an odds ratio (OR) with $95 \%$ confidence intervals (CIs) or the provision of sufficient raw data to calculate these measures. A request letter for the original genotype frequency data was sent to the corresponding author when such data were unavailable in relevant articles. If studies had overlapping data, only the more complete study was used.

\section{Data extraction}

Two investigators collected the following items from each eligible study, independently: name of the first author, year of publication, ethnicity, country, cancer types, genotyping method, source of controls, numbers of cases and controls, genotype frequency of cases and controls, and the demographic data - if available - including smoking status.

\section{Statistical analysis}

This meta-analysis was performed for a recessive model (aa vs Aa+AA, where "A" was the major allele and "a" was the minor allele), dominant model (aa+Aa vs AA), homozygote comparison (aa vs AA), heterozygote comparison (Aa vs AA), and additive model (a vs A). We used ORs with $95 \%$ CIs to evaluate the strength of association between Exol polymorphisms and cancer risk, while pooled ORs were obtained by calculating a weighted average of OR from each study. ${ }^{31}$ Between-study heterogeneity, measured by a $Q$-statistic test ${ }^{32}$ and $I^{2}$ statistic, ${ }^{33}$ was assessed to determine whether a fixed-effects or random-effects model should be applied. When the $P_{\mathrm{h}}$ value of the $Q$-test is smaller than 0.05 , which indicated a significant heterogeneity among the studies, a random-effects model ${ }^{34}$ was used to calculate the pooled ORs; otherwise the fixed-effects model ${ }^{35}$ was used.

Subgroup analyses were performed by ethnicity, source of controls, cancer types, and smoking status to explore the effect of heterogeneity among the studies. Univariate metaregression analysis was used to further clarify the potential reasons for heterogeneity $(P<0.05$ was considered significant). ${ }^{36}$ Studies were split into large sample size or small sample size using the cut-point of 600 participants. By sequentially omitting each study, sensitivity analysis was used to assess the stability of the results. Begg's funnel plot and Egger's linear regression test were carried out to estimate the potential publication bias, graphically and statistically, and $P<0.05$ was considered significant. ${ }^{37}$

A goodness-of-fit $\chi^{2}$ test with 1 degree of freedom was applied to assess the Hardy-Weinberg equilibrium (HWE) in controls and a value of $P<0.05$ was considered as a significant disequilibrium. We used the software program STATA (version 12.0; StataCorp LP, College Station, TX, USA) for all the statistical analyses in this meta-analysis.

\section{Results \\ Extraction process and study characteristics}

On the basis of the inclusion criteria, 17 publications were preliminarily identified as eligible. ${ }^{15-30,38}$ Among these, the study conducted by Yoshiya et $\mathrm{al}^{38}$ was excluded because the data were the same as those for the earlier study by Yamamoto et al. ${ }^{15}$ Thus, 16 articles were included in the final metaanalysis. ${ }^{15-30}$ Table 1 summarizes the main characteristics of the selected studies, while Figure 1 shows the study selection process. The genotyping data in the study by Jin et a $\mathrm{l}^{19}$ were only analyzed in the additive genetic model because the data were limited. In addition, the data from Tang et al's study ${ }^{30}$ 
Table I Characteristics of studies included in the meta-analysis

\begin{tabular}{|c|c|c|c|c|c|c|c|}
\hline Study & Ethnicity & Region & SNPs studied & Cancer types & Genotyping & Control source & Cases/controls \\
\hline Yamamoto et al ${ }^{15}$ & Asian & Japan & 757 & Colorectal & PCR-RFLP & PB & $102 / 110$ \\
\hline Zienolddiny et al ${ }^{16}$ & Caucasian & Norway & 589 & Lung & TaqMan & PB & $256 / 291$ \\
\hline Kim et al ${ }^{17}$ & Asian & Korea & 757 & Colorectal & DHPLC & $\mathrm{HB}$ & $268 / 300$ \\
\hline Chang et $\mathrm{al}^{18}$ & Caucasian & USA & 589,670 & Glioblastoma & Microarray & PB & $112 / 110$ \\
\hline Jin et a $\left.\right|^{19}$ & Asian & $\begin{array}{l}\text { People's Republic } \\
\text { of China }\end{array}$ & $757,589,670$ & Lung & Illumina & $\mathrm{HB}$ & $500 / 517$ \\
\hline Bau et $\mathrm{al}^{20}$ & Asian & Taiwan & $757,589,670$ & Gastric & PCR-RFLP & $H B$ & 179/179 \\
\hline Hsu et $\mathrm{al}^{21}$ & Asian & Taiwan & $757,589,670$ & Lung & PCR-RFLP & $H B$ & $358 / 358$ \\
\hline Tsai et $\mathrm{al}^{22}$ & Asian & Taiwan & $757,589,670$ & Oral & PCR-RFLP & $\mathrm{HB}$ & $680 / 680$ \\
\hline Wang et $\mathrm{a}^{23}$ & Asian & Taiwan & $757,589,670$ & Breast & PCR-RFLP & $\mathrm{HB}$ & $\mathrm{I}, 272 / \mathrm{I}, 272$ \\
\hline Wang et a $\left.\right|^{24}$ & Mixed & Costa Rica & 757 & Cervical & TaqMan & PB & $460 / 431$ \\
\hline Haghighi et al ${ }^{25}$ & Asian & Iran & 757 & Colorectal & PCR-RFLP & $\mathrm{HB}$ & $90 / 98$ \\
\hline $\begin{array}{l}\text { Ibarrola-Villava } \\
\text { et } \mathrm{a}^{26}\end{array}$ & Caucasian & Spain & $757,589,670$ & Melanoma & $\begin{array}{l}\text { Sequenom, } \\
\text { TaqMan, Sequenom }\end{array}$ & $\mathrm{HB}$ & $\begin{array}{l}\text { 684/406, } \\
599 / 379,599 / 379\end{array}$ \\
\hline Bayram et $\mathrm{al}^{27}$ & Caucasian & Turkey & 589 & Hepatocellular & PCR-RFLP & $H B$ & $224 / 224$ \\
\hline Luo et $\mathrm{al}^{28}$ & Asian & $\begin{array}{l}\text { People's Republic } \\
\text { of China }\end{array}$ & 589 & Cervical & PCR-RFLP & $\mathrm{HB}$ & $126 / 278$ \\
\hline Kabzinski et al ${ }^{29}$ & Caucasian & Poland & 589 & Colorectal & TaqMan & NA & $150 / 150$ \\
\hline Tang et $\mathrm{al}^{30}$ & Caucasian & Multiple Regions & 589 & Pancreatic & Illumina & Mixed & $2,023 / 2,112$ \\
\hline
\end{tabular}

Abbreviations: SNP, single nucleotide polymorphism; PCR-RFLP, polymerase chain reaction-restriction fragment length polymorphism; TaqMan, real-time TaqMan analysis; DHPLC, denaturing high-performance liquid chromatography; Sequenom, genotyping was performed using the Sequenom platform; PB, population based; HB, hospital based; NA, not available.

were genome-wide association study data. In the pooled analyses, we included 4,093 cases and 3,834 controls from 10 studies for the Pro757Leu polymorphism, 6,479 cases and 6,550 controls from 12 studies for the Glu589Lys polymorphism, and 3,700 cases and 3,496 controls from 7 studies for

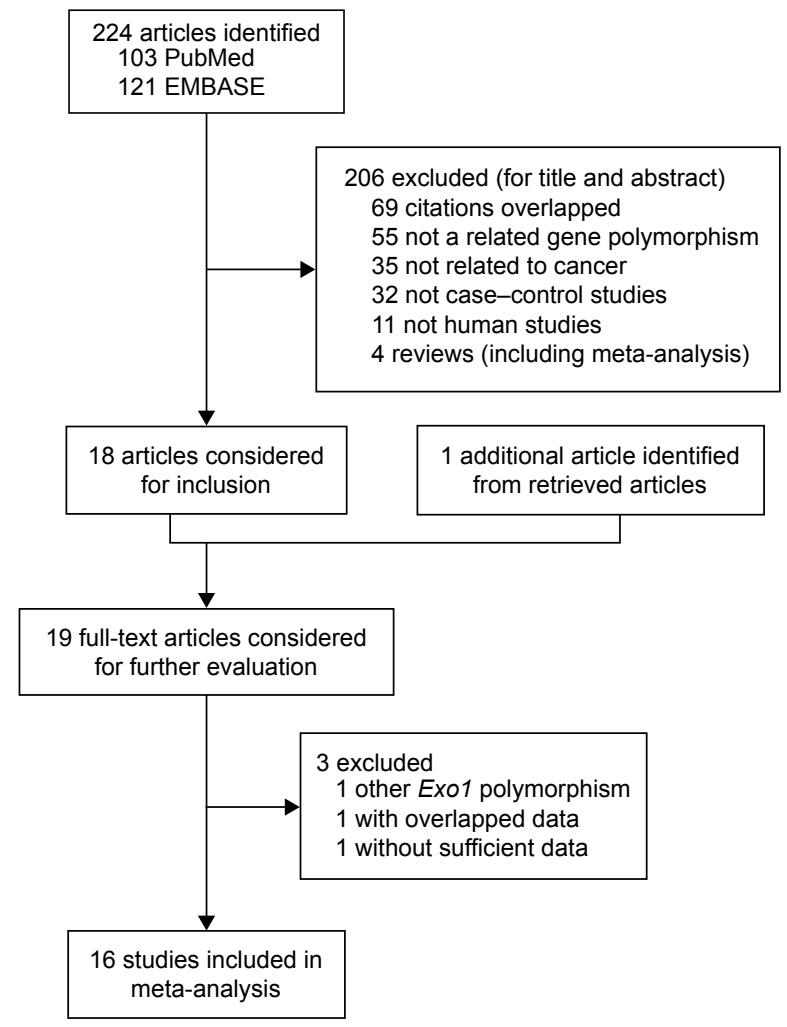

Figure I Studies included in this meta-analysis. the Glu670Gly polymorphism. Of these, six were studies of Caucasians, nine were studies of Asians, and one was a study of mixed population, while four were population based and ten were hospital based. In addition, there were three lung cancer studies, ${ }^{16,19,21}$ four colorectal cancer studies, ${ }^{15,17,25,29}$ two cervical cancer studies, ${ }^{24,28}$ and seven others studies including glioblastoma, ${ }^{18}$ gastric cancer,${ }^{20}$ oral cancer,${ }^{22}$ breast cancer,${ }^{23}$ melanoma, ${ }^{26}$ hepatocellular cancer, ${ }^{27}$ and pancreatic cancer. ${ }^{30}$ Table 2 lists the genotype distribution and allele frequency of Exol polymorphism among cancer cases and controls and the $P$-value of the HWE in the controls.

\section{Meta-analysis results}

The main results for the three Exol polymorphisms of this meta-analysis are listed in Table 3. Overall, the combined results based on all eligible studies showed a significant association between the Pro757Leu polymorphism and reduced cancer risk (dominant model: OR $=0.902,95 \%$ $\mathrm{CI}=0.821-0.991, P=0.032$; and heterozygote comparison: OR $=0.894,95 \%$ CI $=0.809-0.988, P=0.027$; Table 3 ). Moreover, in the stratified analysis, the results showed that the Pro757Leu polymorphism was associated with a reduced risk of cancer among Asians (dominant model: $\mathrm{OR}=0.852$, 95\% CI $=0.765-0.949, P=0.004$; heterozygote comparison: OR $=0.847,95 \%$ CI $=0.755-0.951, P=0.005$; and additive model: $\mathrm{OR}=0.932,95 \% \mathrm{CI}=0.871-0.997, P=0.039$; Figure 2), but not among Caucasians. In the subgroup analysis by source of controls, a significant association was found between the Pro757Leu polymorphism and a reduced 
Table 2 Genotype distribution of Exol polymorphisms used in this study

\begin{tabular}{|c|c|c|c|c|c|c|c|c|c|c|c|c|}
\hline \multirow[t]{2}{*}{ Polymorphism } & \multirow[t]{2}{*}{ Disease } & \multirow[t]{2}{*}{ First author } & \multirow[t]{2}{*}{ Ethnicity } & \multirow{2}{*}{$\begin{array}{l}\text { Sample size } \\
\text { (case/control) }\end{array}$} & \multicolumn{3}{|c|}{ Case } & \multicolumn{3}{|c|}{ Control } & \multirow[t]{2}{*}{ HWE } & \multirow[t]{2}{*}{ MAF } \\
\hline & & & & & AA & $\mathbf{A a}$ & aa & AA & $\mathrm{Aa}$ & aa & & \\
\hline \multirow[t]{10}{*}{ Pro757Leu } & Colorectal & Yamamoto et al ${ }^{15}$ & Asian & $102 / 110$ & 35 & 53 & 14 & 36 & 47 & 27 & 0.143 & 0.459 \\
\hline & Colorectal & Kim et al ${ }^{17}$ & Asian & $268 / 300$ & 108 & 125 & 35 & 99 & 163 & 38 & 0.021 & 0.398 \\
\hline & Lung & Jin et $\mathrm{al}^{19}$ & Asian & $500 / 517$ & - & - & - & - & - & - & - & 0.409 \\
\hline & Gastric & Bau et $\mathrm{al}^{20}$ & Asian & I79/179 & 62 & 78 & 39 & 56 & 84 & 39 & 0.479 & 0.453 \\
\hline & Lung & Hsu et $\mathrm{al}^{21}$ & Asian & $358 / 358$ & 124 & 156 & 78 & 112 & 167 & 79 & 0.264 & 0.454 \\
\hline & Oral & Tsai et $\mathrm{al}^{22}$ & Asian & $680 / 680$ & 235 & 297 & 148 & 214 & 313 & 153 & 0.061 & 0.455 \\
\hline & Breast & Wang et $\mathrm{a}^{23}$ & Asian & $\mathrm{I}, 272 / I, 272$ & 433 & 563 & 276 & 402 & 596 & 274 & 0.057 & 0.450 \\
\hline & Cervical & Wang et $\mathrm{al}^{24}$ & Mixed & $460 / 431$ & 175 & 214 & 71 & 169 & 217 & 45 & 0.042 & 0.356 \\
\hline & Colorectal & Haghighi et a $\left.\right|^{25}$ & Asian & $90 / 98$ & 60 & 28 & 2 & 51 & 37 & 10 & 0.402 & 0.291 \\
\hline & Melanoma & Ibarrola-Villava et $\mathrm{a}^{26}$ & Caucasian & $684 / 406$ & 485 & 186 & 13 & 297 & 99 & 10 & 0.611 & 0.147 \\
\hline \multirow[t]{12}{*}{ Glu589Lys } & Lung & Zienolddiny et al ${ }^{16}$ & Caucasian & $256 / 291$ & 115 & 106 & 35 & 116 & 145 & 30 & 0.117 & 0.352 \\
\hline & Glioblastoma & Chang et $\mathrm{al}^{18}$ & Caucasian & $112 / 110$ & 55 & 42 & 15 & 29 & 59 & 22 & 0.419 & 0.468 \\
\hline & Lung & Jin et $\mathrm{al}^{19}$ & Asian & $500 / 517$ & 304 & 172 & 24 & 355 & 138 & 24 & 0.030 & 0.180 \\
\hline & Gastric & Bau et $\mathrm{al}^{20}$ & Asian & 179/179 & 103 & 64 & 12 & 125 & 49 & 5 & 0.940 & 0.165 \\
\hline & Lung & Hsu et $\mathrm{al}^{21}$ & Asian & $358 / 358$ & 214 & 125 & 19 & 251 & 97 & 10 & 0.865 & 0.163 \\
\hline & Oral & Tsai et $\mathrm{al}^{22}$ & Asian & $680 / 680$ & 391 & 244 & 45 & 482 & 183 & 15 & 0.626 & 0.157 \\
\hline & Breast & Wang et $\mathrm{al}^{23}$ & Asian & $\mathrm{I}, 272 / 1,272$ & 794 & 421 & 57 & 898 & 341 & 33 & 0.926 & 0.160 \\
\hline & Melanoma & Ibarrola-Villava et $\mathrm{a}^{26}$ & Caucasian & $599 / 379$ & 234 & 282 & 83 & 136 & 175 & 68 & 0.373 & 0.410 \\
\hline & Hepatocellular & Bayram et $\mathrm{a}^{27}$ & Caucasian & $224 / 224$ & 95 & 94 & 35 & 99 & 108 & 17 & 0.089 & 0.317 \\
\hline & Cervical & Luo et $\mathrm{al}^{28}$ & Asian & $126 / 278$ & 73 & 48 & 5 & 196 & 77 & 5 & 0.412 & 0.156 \\
\hline & Colorectal & Kabzinski et a ${ }^{29}$ & Caucasian & $150 / 150$ & 22 & 95 & 33 & 49 & 62 & 39 & 0.038 & 0.467 \\
\hline & Pancreatic & Tang et $\mathrm{a}^{30}$ & Caucasian & $2,023 / 2,112$ & 827 & 910 & 286 & 815 & 993 & 304 & 0.956 & 0.379 \\
\hline \multirow[t]{7}{*}{ Glu670Gly } & Glioblastoma & Chang et al ${ }^{18}$ & Caucasian & $112 / 111$ & 44 & 57 & 11 & 46 & 47 & 18 & 0.314 & 0.374 \\
\hline & Lung & Jin et $\mathrm{al}^{19}$ & Asian & $500 / 517$ & - & - & - & - & - & - & - & 0.181 \\
\hline & Gastric & Bau et $\mathrm{al}^{20}$ & Asian & 179/179 & $|3|$ & 39 & 9 & 135 & 36 & 8 & 0.011 & 0.145 \\
\hline & Lung & Hsu et $\mathrm{al}^{21}$ & Asian & $358 / 358$ & 262 & 78 & 18 & 269 & 73 & 16 & 0.000 & 0.147 \\
\hline & Oral & Tsai et $\mathrm{al}^{22}$ & Asian & $680 / 680$ & 497 & 148 & 35 & 511 & 138 & 31 & 0.000 & 0.147 \\
\hline & Breast & Wang et $\mathrm{al}^{23}$ & Asian & $\mathrm{I}, 272 / 1,272$ & 941 & 267 & 64 & 958 & 255 & 59 & 0.000 & 0.147 \\
\hline & Melanoma & Ibarrola-Villava et $\mathrm{a}^{26}$ & Caucasian & $599 / 379$ & 239 & 293 & 67 & 160 & $17 \mid$ & 48 & 0.826 & 0.352 \\
\hline
\end{tabular}

Abbreviations: HWE, Hardy-Weinberg equilibrium; MAF, minor allele frequency; A, the major allele; a, the minor allele.

cancer risk in the dominant model and in the heterozygote comparison in the hospital-based controls (Leu/Leu+Pro/Leu vs Pro/Pro: OR $=0.882,95 \% \mathrm{CI}=0.797-0.977, P=0.016$; Pro/Leu vs Pro/Pro: OR $=0.878,95 \%$ CI $=0.788-0.979$, $P=0.019$; Table 3), but not in the population-based controls. Moreover, the Leu allele of the Pro757Leu polymorphism was significantly associated with a reduced risk of colorectal cancer (dominant model: $\mathrm{OR}=0.724,95 \% \mathrm{CI}=0.557-0.942$, $P=0.016$; homozygote comparison: $\mathrm{OR}=0.633,95 \%$ $\mathrm{CI}=0.417-0.961, P=0.032 ;$ and additive model: $\mathrm{OR}=0.782$, $95 \% \mathrm{CI}=0.648-0.943, P=0.010)$.

In terms of the Exo1 Glu589Lys polymorphism, a statistically significant association was found between the Exol Glu589Lys polymorphism and the risk of cancer in the homozygote comparison (Lys/Lys vs Glu/Glu: OR $=1.447$, $95 \% \mathrm{CI}=1.028-2.035, P=0.034)$ and in the additive model (Lys vs Glu: $\mathrm{OR}=1.200,95 \% \mathrm{CI}=1.014-1.421, P=0.034$ ) in the pooled analyses. For Asians, the results showed that the Glu589Lys polymorphism increased the cancer risk (recessive model: $\mathrm{OR}=1.876,95 \% \mathrm{CI}=1.444-2.436, P<0.001$; dominant model: $\mathrm{OR}=1.555,95 \% \mathrm{CI}=1.401-1.726$, $P<0.001$; homozygote comparison: $\mathrm{OR}=2.133,95 \%$ $\mathrm{CI}=1.639-2.777, P<0.001$; heterozygote comparison: $\mathrm{OR}=1.495,95 \% \mathrm{CI}=1.341-1.666, P<0.001$; and additive model: $\mathrm{OR}=1.487,95 \% \mathrm{CI}=1.361-1.625, P<0.001$ ), while no association was found among Caucasians. When stratified by the source of controls, a significantly elevated cancer risk was found among studies with hospital-based controls (recessive model: $\mathrm{OR}=1.683,95 \% \mathrm{CI}=1.097-2.581$, $P=0.017$; dominant model: $\mathrm{OR}=1.405,95 \% \mathrm{CI}=1.180$ 1.674, $P<0.001$; homozygote comparison: $\mathrm{OR}=1.848$, 95\% CI $=1.164-2.934, P=0.009$; heterozygote comparison: $\mathrm{OR}=1.356,95 \% \mathrm{CI}=1.161-1.583, P<0.001$; and additive model: $\mathrm{OR}=1.366,95 \% \mathrm{CI}=1.144-1.632, P=0.001$ ), while in population-based studies, the results showed that the Glu589Lys polymorphism was associated with a reduced cancer risk only in the heterozygote comparison $(\mathrm{OR}=0.616$, $95 \% \mathrm{CI}=0.453-0.836, P=0.002$ ). In terms of cancer types, no association was found for lung cancer. Furthermore, subgroup analysis was also performed by smoking status. The results 
showed that the Glu589Lys polymorphism was significantly associated with an increased cancer risk in smokers (dominant model: $\mathrm{OR}=1.866,95 \% \mathrm{CI}=1.384-2.515, P<0.001$; Table 4, Figure 3), but not in nonsmokers.

In terms of the Exol Glu670Gly polymorphism, no evidence was found for an association between the Glu670Gly polymorphism and cancer risk for all genetic models (Table 3). Furthermore, the results in the subgroup analyses by ethnicity, source of controls, and cancer types revealed no association, either.

\section{Test of heterogeneity}

The heterogeneity test showed that no significant heterogeneity was found for the Pro757Leu and Glu670Gly polymorphisms in all comparisons (Table 3). However, there was significant between-study heterogeneity for the Exol Glu589Lys polymorphism in all genetic models (Table 3). Subgroup analysis was performed to explore the potential sources of heterogeneity. After patients were stratified by ethnicity, no heterogeneity was found in the Asian population, which indicated that ethnicity may contribute to substantial heterogeneity for the Glu589Lys polymorphism. A series of univariate meta-regression analyses under all genetic models, with the covariates of ethnicity, publication year, sample size, and HWE, showed that only ethnicity had a significant influence on heterogeneity (recessive model: $P=0.029$; dominant model: $P=0.035$; homozygote comparison: $P=0.032$; and additive model: $P=0.004$; Table 5).

\section{Sensitivity analysis}

Sensitivity analysis was performed to assess the influence of each individual study on the pooled ORs. The results showed that the conclusions of this meta-analysis for the Glu670Gly polymorphism were relatively stable and credible because the overall ORs were not influenced excessively by omitting any single study (data not shown). However, the conclusions for the Pro757Leu and Glu589Lys polymorphism were not sufficiently stable. While excluding any one of the three studies, ${ }^{17,22,23}$ the pooled ORs for the Pro757Leu polymorphism changed and the result became negative in all genetic models, indicating that the results were relatively unstable. In terms of the Glu589Lys polymorphism, when the study by Chang et a ${ }^{18}$ was excluded, the association between the Exo1 Glu589Lys polymorphism and the risk of cancer became significant in all genetic models (recessive model: $\mathrm{OR}=1.399,95 \% \mathrm{CI}=1.048-1.866, P=0.022$; dominant model: $\mathrm{OR}=1.333,95 \% \mathrm{CI}=1.086-1.637, P=0.006$; homozygote comparison: $\mathrm{OR}=1.601,95 \% \mathrm{CI}=1.144-2.240$,
$P=0.006$; heterozygote comparison: $\mathrm{OR}=1.294,95 \%$ $\mathrm{CI}=1.055-1.587, P=0.013$; and additive model: $\mathrm{OR}=1.269$, $95 \% \mathrm{CI}=1.079-1.494, P=0.004)$, suggesting that this study significantly influenced the result.

\section{Publication bias}

The publication bias of the literature was assessed by both Begg's funnel plot and Egger's test. The shapes of the funnel plots for each polymorphism showed no obvious asymmetry (Figure 4). Evidence of publication bias was not found using Egger's test for the Pro757Leu polymorphism (recessive model: $P=0.188$; dominant model: $P=0.357$; homozygote comparison: $P=0.188$; heterozygote comparison: $P=0.734$; and additive model: $P=0.178$ ), Glu589Lys polymorphism (recessive model: $P=0.093$; dominant model: $P=0.516$; homozygote comparison: $P=0.081$; heterozygote comparison: $P=0.556$; and additive model: $P=0.310$ ), and Glu670Gly polymorphism (recessive model: $P=0.679$; dominant model: $P=0.193$; homozygote comparison: $P=0.608$; heterozygote comparison: $P=0.098$; and additive model: $P=0.666)$, respectively.

\section{Discussion}

Our meta-analysis is the first study to investigate the association between Exo1 Pro757Leu and Glu670Gly polymorphisms of Exo1 and cancer susceptibility, and also the largest and most comprehensive assessment of the relationship between the Glu589Lys polymorphism and cancer risk. In our study, we conducted an analysis that included 10 studies relating to the Pro757Leu polymorphism (4,093 cases and 3,834 controls), 12 studies relating to the Glu589Lys polymorphism $(6,479$ cases and 6,550 controls), and 7 studies relating to the Glu670Gly polymorphism (3,700 cases and 3,496 controls). The final results showed that Pro757Leu conferred a protective effect against cancer, and the Glu589Lys polymorphism was associated with an increased cancer risk, but the Glu670Gly polymorphism was not statistically significantly associated with cancer risk. Interestingly, stratified analysis by ethnicity indicated that, among Asians, the Pro757Leu polymorphism was associated with a reduced risk of cancer under the dominant model, heterozygote comparison, and additive model, whereas the Glu589Lys polymorphism was significantly associated with increased cancer risk under all the genetic models. The differences between Asians and other races may be partly due to the different genetic backgrounds and environments or lifestyles. ${ }^{39}$ The Leu allele frequency of the Pro757Leu polymorphism among the controls in the Asian population was $43.7 \%$ (95\% $\mathrm{CI}=42.5 \%-44.8 \%$ ), which was significantly higher than that 
Table 3 Results of meta-analysis for Exol polymorphisms and the risk of cancer

\begin{tabular}{|c|c|c|c|c|c|c|c|}
\hline \multicolumn{2}{|c|}{ Genetic model } & \multirow{2}{*}{\multicolumn{3}{|c|}{$\frac{\text { Recessive model }}{\text { Leu/Leu vs Pro/Leu+Pro/Pro }}$}} & \multirow{2}{*}{\multicolumn{3}{|c|}{$\begin{array}{l}\text { Dominant model } \\
\text { Leu/Leu+Pro/Leu vs Pro/Pro }\end{array}$}} \\
\hline \multirow[t]{2}{*}{ Pro757Leu } & \multirow{2}{*}{$\begin{array}{l}\text { Number of } \\
\text { studies } \\
\text { ( } \mathbf{n} \text { of cases/ } \\
\mathbf{n} \text { of controls) }\end{array}$} & & & & & & \\
\hline & & OR $(95 \% \mathrm{Cl})$ & $P_{h}$ & $I^{2}(\%)$ & OR (95\% CI) & $P_{h}$ & $I^{2}(\%)$ \\
\hline Total & $10(4,593 / 4,35 \mathrm{I})$ & $0.995(0.883-1.122)$ & 0.098 & 40.4 & $0.902(0.82 I-0.99 \mid)$ & 0.419 & 1.8 \\
\hline \multicolumn{8}{|l|}{ Ethnicity } \\
\hline Asian & $8(3,449 / 3,5 \mid 4)$ & $0.955(0.842-1.084)$ & 0.252 & 23.2 & $0.852(0.765-0.949)$ & 0.744 & 0.0 \\
\hline Caucasian & I (684/406) & $0.767(0.333-1.766)$ & - & - & I.I I8 (0.850-I.47I) & - & - \\
\hline Mixed & I (460/43 I) & $1.566(1.050-2.334)$ & - & - & $1.050(0.802-1.376)$ & - & - \\
\hline \multicolumn{8}{|l|}{ CS } \\
\hline PB & $2(562 / 540)$ & $0.910(0.292-2.838)$ & 0.005 & 87.2 & $1.028(0.805-1.3 \mid 2)$ & 0.708 & 0.0 \\
\hline $\mathrm{HB}$ & $8(4,03 \mathrm{I} / 3,8 \mathrm{I} I)$ & $0.972(0.856-1.105)$ & 0.600 & 0.0 & $0.882(0.797-0.977)$ & 0.347 & 10.8 \\
\hline \multicolumn{8}{|l|}{ Cancer } \\
\hline Colorectal & $3(728 / 768)$ & $0.717(0.489-1.050)$ & 0.053 & 66.0 & $0.724(0.557-0.942)$ & 0.435 & 0 \\
\hline Lung & $2(858 / 875)$ & $0.984(0.690-1.402)$ & - & - & $0.859(0.629-1.174)$ & - & - \\
\hline \multicolumn{8}{|l|}{ HWE } \\
\hline Yes & $7(3,365 / 3,103)$ & $0.945(0.830-1.076)$ & 0.240 & 24.8 & $0.900(0.810-0.999)$ & 0.488 & 0.0 \\
\hline No & $3(1,228 / 1,248)$ & I.33। (0.978-I.8I2) & 0.201 & 38.8 & $0.914(0.739-1.129)$ & 0.102 & 62.7 \\
\hline \multirow[t]{2}{*}{ Glu589Lys } & $\mathbf{n}$ & \multicolumn{3}{|c|}{ Lys/Lys vs Glu/Lys+Glu/Glu } & \multicolumn{3}{|c|}{ Lys/Lys+Glu/Lys vs Glu/Glu } \\
\hline & & OR (95\% Cl) & $P_{h}$ & $I^{2}(\%)$ & OR (95\% Cl) & $P_{h}$ & $I^{2}(\%)$ \\
\hline Total & $12(6,479 / 6,550)$ & $1.320(0.999-1.744)$ & 0.000 & 71.6 & $1.237(0.995-1.538)$ & 0.000 & 86.6 \\
\hline \multicolumn{8}{|l|}{ Ethnicity } \\
\hline Asian & $6(3,|| 5 / 3,2 \mid 4)$ & $\mathrm{I} .876(\mathrm{I} .444-2.436)$ & 0.194 & 32.2 & $\mathrm{I} .555(\mathrm{I} .40 \mathrm{I}-\mathrm{I} .726)$ & 0.650 & 0.0 \\
\hline Caucasian & $6(3,364 / 3,266)$ & $1.000(0.75 I-1.332)$ & 0.019 & 62.9 & $0.936(0.697-1.257)$ & 0.000 & 81.0 \\
\hline \multicolumn{8}{|l|}{ CS } \\
\hline PB & $2(368 / 40 I)$ & $1.042(0.687-1.580)$ & 0.076 & 68.2 & $0.568(0.264-1.221)$ & 0.019 & 81.7 \\
\hline $\mathrm{HB}$ & $8(5,96 \mathrm{I} / 5,999)$ & $\mathrm{I} .683(\mathrm{I} .097-2.58 \mathrm{I})$ & 0.000 & 74.0 & $1.405(1.180-1.674)$ & 0.004 & 66.9 \\
\hline \multicolumn{8}{|l|}{ Cancer } \\
\hline Lung & $3(I, I \mid 4 / 1,166)$ & I.338 (0.948-I.888) & 0.436 & 0.0 & I.23। (0.848-I.787) & 0.010 & 78.2 \\
\hline \multicolumn{8}{|l|}{ HWE } \\
\hline Yes & $10(5,829 / 5,883)$ & $1.444(1.039-2.005)$ & 0.000 & 75.7 & I. I $49(0.908-1.454)$ & 0.000 & 87.2 \\
\hline No & $2(650 / 667)$ & $0.902(0.610-1.334)$ & 0.525 & 0.0 & $1.904(0.972-3.727)$ & 0.029 & 78.9 \\
\hline \multirow[t]{2}{*}{ Glu670Gly } & $\mathbf{n}$ & \multicolumn{3}{|c|}{ Glu/Glu vs Gly/Glu+Gly/Gly } & \multicolumn{3}{|c|}{ Glu/Glu+Gly/Glu vs Gly/Gly } \\
\hline & & OR $(95 \% \mathrm{Cl})$ & $P_{\mathrm{h}}$ & $I^{2}(\%)$ & OR $(95 \% \mathrm{Cl})$ & $P_{h}$ & $I^{2}(\%)$ \\
\hline Total & $7(3,700 / 3,496)$ & $0.989(0.802-1.219)$ & 0.683 & 0.0 & $1.094(0.978-1.224)$ & 1.000 & 0.0 \\
\hline \multicolumn{8}{|l|}{ Ethnicity } \\
\hline Asian & $5(2,989 / 3,006)$ & I.I II (0.857-I.440) & 0.999 & 0.0 & I.093 (0.962-I.24I) & 0.994 & 0.0 \\
\hline Caucasian & $2(711 / 490)$ & $0.796(0.559-1.132)$ & $0.34 I$ & 0.0 & $1.099(0.869-1.390)$ & 0.984 & 0.0 \\
\hline \multicolumn{8}{|l|}{ CS } \\
\hline PB & $I(\mid I 2 / I I I)$ & $0.563(0.253-1.254)$ & - & - & $1.094(0.640-1.868)$ & - & - \\
\hline $\mathrm{HB}$ & $6(3,588 / 3,385)$ & I.032 (0.830-I.282) & 0.900 & 0.0 & $1.094(0.976-1.227)$ & 0.999 & 0.0 \\
\hline \multicolumn{8}{|l|}{ Cancer } \\
\hline Lung & $2(858 / 875)$ & I.I32(0.568-2.256) & - & - & I.I $07(0.792-1.548)$ & - & - \\
\hline
\end{tabular}

Notes: Random-effects model was used when $P$-value for heterogeneity test $<0.05$; otherwise, fixed-model was used.

Abbreviations: CS, control source; PB, population based; HB, hospital based; $P_{\mathrm{h}}$, $P$-values for heterogeneity from $Q$-test; HWE, Hardy-Weinberg equilibrium; OR, odds ratio; $95 \% \mathrm{Cl}$, $95 \%$ confidence interval; $n$, number.

in the Caucasian population $(14.7 \%, 95 \% \mathrm{CI}=12.2 \%-17.1 \%$, $P<0.001)$. On the contrary, the Lys and Gly allele frequency of the Glu589Lys and Glu670Gly polymorphisms in Asians was 16.3\% (95\% CI $=15.4 \%-17.2 \%)$ and $15.3 \%$ (95\% CI $=14.3 \%-16.2 \%)$, which was significantly lower than that in Caucasians $(38.3 \%, 95 \% \mathrm{CI}=37.1 \%-39.5 \%$, $P<0.001$, and 35.7\%, 95\% CI =32.7\%-38.7\%, $P<0.001$ ). In subgroup analysis of the different sources of controls, significant associations were found between the Pro757Leu polymorphism and reduced cancer risk, while evidence of an association between the Glu589Lys polymorphism and an increased cancer risk was found in the hospital-based studies, but not in the population-based studies. This may be because the hospital-based controls may have sickness that was connected with the genotypes under investigation, leading to potential biases. ${ }^{40}$ Furthermore, there was a significantly 


\begin{tabular}{|c|c|c|c|c|c|c|c|c|}
\hline \multicolumn{3}{|l|}{ Homozygote } & \multicolumn{3}{|l|}{ Heterozygote } & \multicolumn{3}{|l|}{ Additive model } \\
\hline \multicolumn{3}{|l|}{ Leu/Leu vs Pro/Pro } & \multicolumn{3}{|l|}{ Pro/Leu vs Pro/Pro } & \multicolumn{3}{|l|}{ Leu vs Pro } \\
\hline OR (95\% Cl) & $P_{h}$ & $I^{2}(\%)$ & OR $(95 \% \mathrm{Cl})$ & $P_{h}$ & $I^{2}(\%)$ & OR (95\% Cl) & $P_{h}$ & $I^{2}(\%)$ \\
\hline $0.920(0.805-1.053)$ & 0.154 & 33.0 & $0.894(0.809-0.988)$ & 0.530 & 0.0 & $0.960(0.902-1.020)$ & 0.188 & 27.9 \\
\hline $0.872(0.755-1.007)$ & 0.410 & 1.9 & $0.847(0.755-0.95 \mathrm{I})$ & 0.809 & 0.0 & $0.932(0.87 \mid-0.997)$ & $0.34 I$ & 11.4 \\
\hline $0.796(0.345-1.838)$ & - & - & I.I5I (0.867-I.527) & - & - & I.068 (0.837-I.362) & - & - \\
\hline $1.524(0.992-2.340)$ & - & - & $0.952(0.7 \mid 7-1.264)$ & - & - & I.I4I (0.94I-I.383) & - & - \\
\hline $0.953(0.343-2.65 I)$ & 0.023 & 80.7 & $0.986(0.763-1.275)$ & 0.565 & 0.0 & I.056 (0.890-I.255) & 0.080 & 67.5 \\
\hline $0.884(0.766-1.022)$ & 0.592 & 0.0 & $0.878(0.788-0.979)$ & 0.417 & 0.9 & $0.946(0.886-1.010)$ & 0.330 & 12.8 \\
\hline $0.633(0.417-0.961)$ & 0.135 & 50.2 & $0.766(0.58 I-1.009)$ & 0.315 & 13.5 & $0.782(0.648-0.943)$ & 0.208 & 36.2 \\
\hline $0.892(0.595-1.336)$ & - & - & $0.844(0.603-I . \mid 8 I)$ & - & - & $0.988(0.863-I .130)$ & 0.450 & 0.0 \\
\hline $0.872(0.753-1.010)$ & 0.407 & 2.4 & $0.906(0.810-1.013)$ & 0.532 & 0.0 & $0.933(0.868-1.004)$ & 0.283 & 19.3 \\
\hline $1.210(0.868-1.687)$ & 0.091 & 64.9 & $0.847(0.679-1.058)$ & 0.193 & 41.0 & $1.027(0.916-1.151)$ & 0.207 & 36.5 \\
\hline \multicolumn{3}{|l|}{ Lys/Lys vs Glu/Glu } & \multicolumn{3}{|l|}{ Glu/Lys vs Glu/Glu } & \multicolumn{3}{|l|}{ Lys vs Glu } \\
\hline OR (95\% Cl) & $\boldsymbol{P}_{\mathrm{h}}$ & $I^{2}(\%)$ & OR $(95 \% \mathrm{Cl})$ & $\boldsymbol{P}_{\mathrm{h}}$ & $I^{2}(\%)$ & OR $(95 \% \mathrm{Cl})$ & $\boldsymbol{P}_{\mathrm{h}}$ & $I^{2}(\%)$ \\
\hline I.447 (I.028-2.035) & 0.000 & 79.0 & I.208 (0.974-I.498) & 0.000 & 84.8 & $1.200(\mathrm{I} .0 \mathrm{I} 4-\mathrm{I} .42 \mathrm{I})$ & 0.000 & 86.7 \\
\hline 2.133 (I.639-2.777) & 0.161 & 36.8 & I.495 (I.34I-I.666) & 0.903 & 0.0 & I.487 (I.36I-I.625) & 0.330 & 13.3 \\
\hline $1.016(0.701-1.475)$ & 0.002 & 73.1 & 0.931 (0.673-1.288) & 0.000 & 82.5 & $0.954(0.807-I .128)$ & 0.004 & 71.0 \\
\hline $0.674(0.21 \mathrm{I}-2.15 \mathrm{I})$ & 0.016 & 82.6 & $0.616(0.453-0.836)$ & 0.058 & 72.1 & $0.734(0.4 \mid 5-1.297)$ & 0.013 & 83.8 \\
\hline $1.848(1.164-2.934)$ & 0.000 & 76.5 & $1.356(1.16 \mathrm{I}-1.583)$ & 0.033 & 54.0 & $1.366(1.144-1.632)$ & 0.000 & 78.9 \\
\hline $1.346(0.944-1.92 I)$ & 0.362 & 1.5 & I. I 88 (0.777-I.8I6) & 0.004 & 81.5 & $\mathrm{I} .230(0.96 \mathrm{I}-\mathrm{I} .574)$ & 0.046 & 67.5 \\
\hline I.45। (0.975-2.I58) & 0.000 & 82.1 & I. $104(0.884-1.378)$ & 0.000 & 84.0 & I.I8I (0.97I-I.436) & 0.000 & 88.8 \\
\hline $\mathrm{I} .434(0.90 \mathrm{I}-2.282)$ & 0.298 & 7.8 & $2.135(0.930-4.901)$ & 0.011 & 84.6 & I.298 (I.084-I.554) & 0.884 & 0.0 \\
\hline \multicolumn{3}{|l|}{ Glu/Glu vs Gly/Gly } & \multicolumn{3}{|l|}{ Gly/Glu vs Gly/Gly } & \multicolumn{3}{|l|}{ Glu vs Gly } \\
\hline OR $(95 \% \mathrm{Cl})$ & $\boldsymbol{P}_{\mathrm{h}}$ & $I^{2}(\%)$ & OR $(95 \% \mathrm{CI})$ & $P_{h}$ & $I^{2}(\%)$ & OR $(95 \% \mathrm{Cl})$ & $P_{\mathrm{h}}$ & $I^{2}(\%)$ \\
\hline $1.037(0.837-1.286)$ & 0.861 & 0.0 & I. 104 (0.978-I.245) & 0.994 & 0.0 & I.057 (0.97I-I.I5I) & 0.982 & 0.0 \\
\hline I.I3I (0.87I-I.468) & 0.998 & 0.0 & I.084 (0.944-I.244) & 0.996 & 0.0 & I.078 (0.977-I.I89) & 0.994 & 0.0 \\
\hline $0.867(0.595-1.263)$ & 0.435 & 0.0 & I. 169 (0.9|3-I.497) & 0.755 & 0.0 & $0.997(0.840-1.182)$ & 0.617 & 0.0 \\
\hline $0.639(0.27|-| .504)$ & - & - & $1.268(0.720-2.232)$ & - & - & $0.912(0.620-1.342)$ & - & - \\
\hline 1.072 (0.859-I.339) & 0.963 & 0.0 & $1.096(0.969-1.240)$ & 0.996 & 0.0 & $1.065(0.976-1.162)$ & 0.992 & 0.0 \\
\hline I.I55 (0.577-2.3।3) & - & - & I.097 (0.764-I.575) & - & - & I.062 (0.890-I.267) & 0.748 & 0.0 \\
\hline
\end{tabular}

negative correlation between the Leu allele of the Pro757Leu polymorphism and colorectal cancer risk. However, this result should be interpreted with caution because only three studies (728 cases and 768 controls) were included in the analysis. Moreover, subgroup analysis was also performed under smoking conditions for the Glu589Lys polymorphism. The results showed that the Glu589Lys polymorphism was significantly associated with an increased cancer risk in smokers, but not in nonsmokers, which indicated that cigarette smoking can cause DNA damage and influence the DNA repair activity, which then alters the cancer risk. There was no evidence for an association between the Glu670Gly polymorphism and cancer risk in subgroup analyses based on ethnicity, source of controls, and cancer types. In the future, larger well-designed studies will be needed to validate these associations. 


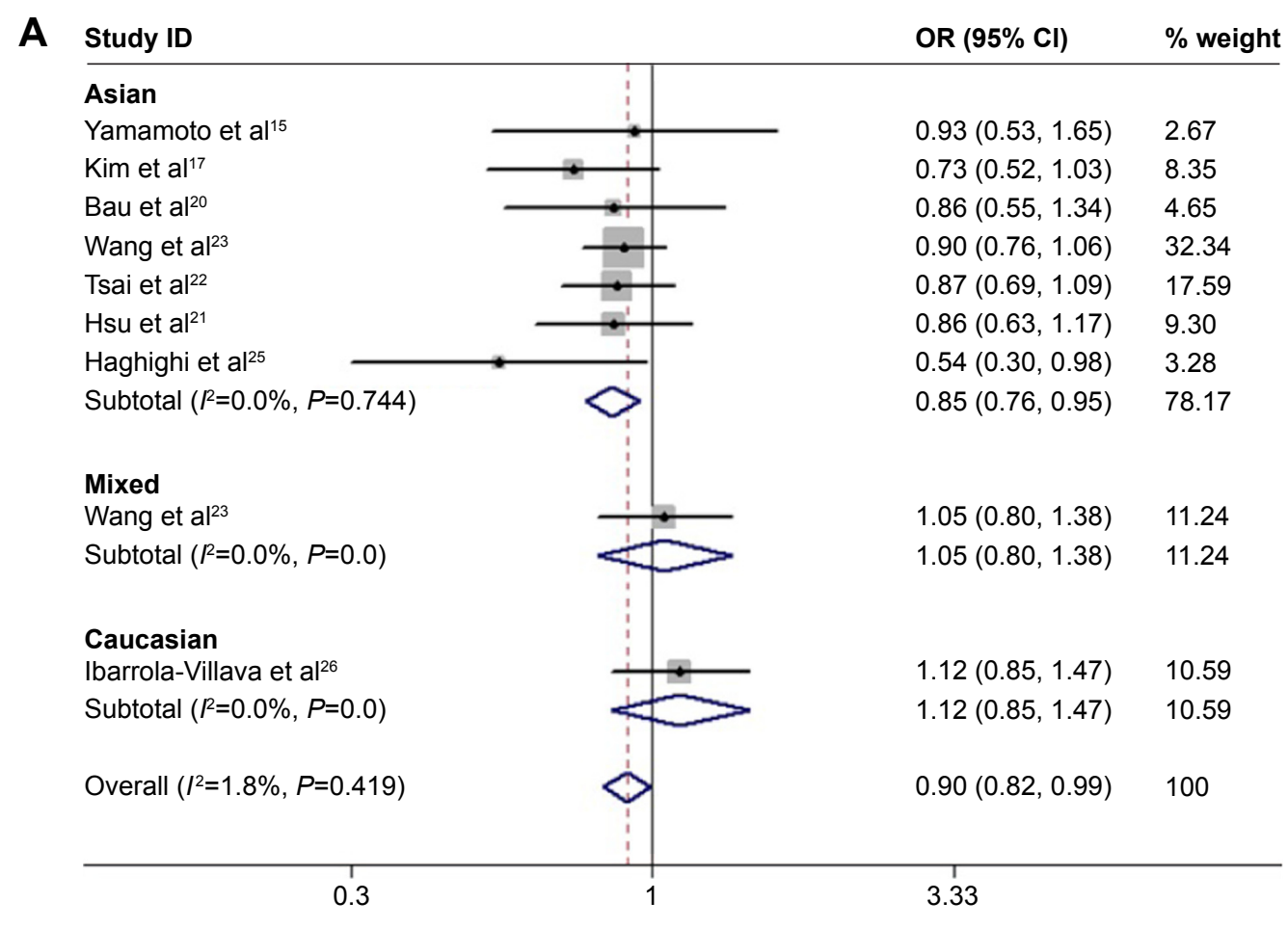

\begin{tabular}{|c|c|c|}
\hline Study ID & OR (95\% Cl) & $\%$ weight \\
\hline \multicolumn{3}{|l|}{ Asian } \\
\hline Yamamoto et al ${ }^{15}$ & $1.16(0.63,2.13)$ & 2.37 \\
\hline Kim et al ${ }^{17}$ & $0.70(0.49,1.01)$ & 8.75 \\
\hline Bau et al20 & $0.84(0.52,1.35)$ & 4.58 \\
\hline Wang et $\mathrm{al}^{23}$ & $0.88(0.73,1.05)$ & 31.85 \\
\hline Tsai et al ${ }^{22}$ & $0.86(0.68,1.10)$ & 17.09 \\
\hline Hsu et al ${ }^{21}$ & $0.84(0.60,1.18)$ & 9.12 \\
\hline Haghighi et al ${ }^{25}$ & $0.64(0.35,1.19)$ & 3.10 \\
\hline Subtotal $\left(I^{2}=0.0 \%, P=0.809\right)$ & $0.85(0.75,0.95)$ & 76.87 \\
\hline \multicolumn{3}{|l|}{ Mixed } \\
\hline Wang et al ${ }^{23}$ & $0.95(0.72,1.26)$ & 12.06 \\
\hline Subtotal $\left(I^{2}=0.0 \%, P=0.0\right)$ & $0.95(0.72,1.26)$ & 12.06 \\
\hline \multicolumn{3}{|l|}{ Caucasian } \\
\hline $\begin{array}{l}\text { Ibarrola-Villava et a }\left.\right|^{26} \\
\text { Subtotal }\left(I^{2}=0.0 \%, P=0.0\right)\end{array}$ & $\begin{array}{l}1.15(0.87,1.53) \\
1.15(0.87,1.53)\end{array}$ & 11.07 \\
\hline Subtotal $\left(I^{2}=0.0 \%, P=0.530\right)$ & $0.89(0.81,0.99)$ & 100 \\
\hline 0.347 & 2.88 & \\
\hline
\end{tabular}

Figure 2 Forest plots of ORs with $95 \% \mathrm{Cl}$ for Exol Pro757Leu polymorphism and the risk of cancer observed in subgroup analyses by ethnicity.

Notes: The center of each square represents the OR, the area of the square represents the sample number and thus the weight used in the meta-analysis, and the horizontal line indicates the $95 \% \mathrm{Cl}$. (A) Dominant model; (B) heterozygote comparison.

Abbreviations: OR, odds ratio; $95 \% \mathrm{Cl}, 95 \%$ confidence interval.

In this study, there was significant heterogeneity between studies relating to the Glu589Lys polymorphism, but not to the other two polymorphisms. To explore the sources of heterogeneity, studies were classified according to ethnicity, source of controls, cancer type, and sample size. The results showed that the heterogeneity was significantly reduced in the Asian population subgroup, which indicated that ethnicity could partly explain the source of heterogeneity. The studies for the Caucasian population yielded different results, with high heterogeneity, revealing the necessity for further study. 
Table 4 Results of stratified analysis by smoking status for Exol Glu589Lys polymorphism in dominant model (Lys/Lys+Glu/Lys vs Glu/Glu)

\begin{tabular}{|c|c|c|c|c|}
\hline \multirow[t]{2}{*}{ Smoking } & \multirow{2}{*}{$\begin{array}{l}\text { Number of } \\
\text { studies } \\
\text { ( } \mathrm{n} \text { of cases/ } \\
\mathbf{n} \text { of controls) }\end{array}$} & \multicolumn{3}{|c|}{ Lys/Lys+Glu/Lys vs Glu/Glu } \\
\hline & & OR (95\% Cl) & $P_{\mathrm{h}}$ & $I^{2}(\%)$ \\
\hline & $4(I, 268 / I, I 5 I)$ & $1.866(1.384-2.515)$ & 0.038 & 64.5 \\
\hline Nonsmokers & $4(449 / 583)$ & I.II4 (0.862-I.440) & 0.148 & 43.9 \\
\hline
\end{tabular}

Notes: Random-effects model was used when $P$-value for heterogeneity test $<0.05$; otherwise, fixed-model was used.

Abbreviations: $P_{\mathrm{h}}, P$-values for heterogeneity from $Q$-test; $O R$, odds ratio; $95 \% \mathrm{Cl}$, $95 \%$ confidence interval; $n$, number.

Likewise, the metaregression analysis identified ethnicity as an important contributor to heterogeneity. Furthermore, the sensitivity analysis showed that the study by Chang et al ${ }^{18}$ could have an influence on the overall results for Glu589Lys polymorphism because it was the only study to reveal that the Glu589Lys polymorphism was significantly related to reduced cancer risk. Although the three studies by Kim et al, ${ }^{17}$ Tsai et al, ${ }^{22}$ and Wang et al ${ }^{23}$ may affect the overall results for the Pro757Leu polymorphism, none of the studies led to a change in conclusions for the Asian population, indicating that the results for the Asian population were relatively stable and credible. Additionally, the overall results for the Pro757Leu and Glu589Lys polymorphisms were dominated by the conclusions for the Asian population, which indicated that ethnicity was an important factor in Exo1 SNPs and should be carefully considered in future studies.

Many previous studies have investigated the association between the Pro757Leu polymorphism and cancer risk. Studies performed by Yamamoto et al, ${ }^{15} \mathrm{Kim}$ et al, ${ }^{17}$ and
Haghighi et $\mathrm{al}^{25}$ revealed that the Leu/Leu genotype is associated with reduced risk of colorectal cancer in Asians, which concurred with our results of subgroup analysis on ethnicity and cancer types. However, the results of some studies differ from our own results, ${ }^{19-22}$ which may be attributed to the limitation of sample size. Similarly, in terms of the Glu589Lys polymorphism, the studies for the Asian population uniformly showed that individuals with the Glu/Lys or Lys/Lys genotypes had a significantly increased cancer risk, including an increased risk of lung, gastric, breast, oral, and cervical cancer, which concurred with our own conclusion. ${ }^{19-23,28}$ Moreover, some other studies found no statistical association between the Glu589Lys polymorphism and cancer risk in the Caucasian population, which was also in line with our own results for Caucasians. ${ }^{16,26,30}$ In terms of the Glu670Gly polymorphism, we found no significant association with cancer risk, which was consistent with the results of previous studies. ${ }^{18-23,26}$

Interestingly, Bayram ${ }^{41}$ and Duan et $\mathrm{al}^{42}$ have conducted meta-analyses to identify whether there was any evidence of a relationship between the Exo1 Glu589Lys polymorphism and cancer susceptibility. Their conclusions could be considered to be inconsistent, which may be partially attributable to the relatively small sample size. The meta-analysis by Bayram $^{41}$ showed that the Glu589Lys polymorphism was not associated with overall cancer susceptibility, which contrasted with our own results. However, we found that the data reported by Bayram ${ }^{41}$ from the studies by Wang et $\mathrm{al}^{23}$ and Ibarrola-Villava et $\mathrm{al}^{26}$ were not the same as the original data. Another recent meta-analysis by Duan et al ${ }^{42}$ concluded that the Glu589Lys polymorphism was significantly associated with increased cancer risk in all genetic

\begin{tabular}{|c|c|c|}
\hline Study ID & OR $(95 \% \mathrm{Cl})$ & $\%$ weight \\
\hline Jin et $a^{19}$ & $1.34(0.96,1.89)$ & 26.22 \\
\hline Bau et $\mathrm{al}^{20}$ & $2.07(1.22,3.50)$ & 17.79 \\
\hline Tsai et $\mathrm{al}^{22}$ & $2.51(1.91,3.29)$ & 30.00 \\
\hline Hsu et $a^{21}$ & $1.72(1.22,2.43)$ & 25.99 \\
\hline Overall $\left(I^{2}=64.5 \%, P=0.038\right)$ & $1.87(1.38,2.51)$ & 100 \\
\hline 0.286 & & \\
\hline
\end{tabular}

Figure 3 Forest plot of ORs with $95 \% \mathrm{Cl}$ for the Exol Glu589Lys polymorphism and the risk of cancer for the dominant model (Lys/Lys+Glu/Lys vs Glu/Glu) in smokers. Notes: The center of each square represents the OR, the area of the square represents the sample number and thus the weight used in the meta-analysis, and the horizontal line indicates the $95 \% \mathrm{Cl}$. Weights are from random effects analysis.

Abbreviations: OR, odds ratio; $95 \% \mathrm{Cl}, 95 \%$ confidence interval. 
Table 5 Univariate meta-regression analysis for heterogeneity of Glu589Lys polymorphism

\begin{tabular}{|c|c|c|c|c|c|c|c|c|c|c|}
\hline \multirow[t]{2}{*}{ Covariates } & \multicolumn{2}{|c|}{ Recessive model } & \multicolumn{2}{|c|}{ Dominant model } & \multicolumn{2}{|c|}{ Homozygote } & \multicolumn{2}{|c|}{ Heterozygote } & \multicolumn{2}{|c|}{ Additive model } \\
\hline & Coefficient & $P$-value & Coefficient & $P$-value & Coefficient & $P$-value & Coefficient & $P$-value & Coefficient & $P$-value \\
\hline Ethnicity & -0.638 & 0.029 & -0.535 & 0.035 & -0.768 & 0.032 & -0.501 & 0.111 & -0.456 & 0.003 \\
\hline Year & -0.044 & 0.493 & 0.052 & 0.408 & 0.015 & 0.859 & 0.063 & 0.330 & 0.007 & 0.867 \\
\hline SS & 0.016 & 0.961 & 0.087 & 0.777 & 0.000 & 0.999 & 0.109 & 0.730 & 0.082 & 0.690 \\
\hline HWE & -0.464 & 0.275 & 0.506 & 0.205 & 0.008 & 0.989 & 0.636 & 0.114 & 0.099 & 0.718 \\
\hline
\end{tabular}

Abbreviations: SS, sample size; HWE, Hardy-Weinberg equilibrium.

models, which differed from our own results. This may be explained by the relatively small sample size. At least four eligible studies ${ }^{16,26,29,30}$ were not included in the meta-analysis by Duan et $\mathrm{al},{ }^{42}$ while the study by Jin et $\mathrm{a}{ }^{19}$ was excluded because their controls deviated from the HWE. Compared with the previous study, five additional studies ${ }^{16,19,26,29,30}$ with 3,528 cases and 3,449 controls in total - were included in our meta-analysis, from which more solid evidence could be provided on the association between the Glu589Lys polymorphism and cancer risk.

Some limitations of our meta-analysis should also be considered when interpreting the results. First, there was an insufficient number of studies collected in this analysis to explore a true association between Exol polymorphisms and cancer risk, especially in terms of the stratified analyses.
Second, owing to lack of original data, an evaluation of gene-gene, gene-environment, and different polymorphism loci interactions, which may alter cancer risk, could not be carried out in our study. In fact, the study conducted by Yamamoto et $\mathrm{al}{ }^{15}$ had studied the combined effects of two SNPs of Exol on cancer risk. Third, serious confounding bias may exist because we calculated only unadjusted ORs; other risk factors such as age, sex, smoking status, and other variables were not adjusted. A more precise analysis should be conducted if more detailed personal data are available. Fourth, we used only published and English articles, which may bias the results, although the funnel plot and Egger's test did not indicate remarkable publication bias. Despite the limitations, the advantages of this meta-analysis should also be acknowledged. First, the statistical power was significantly
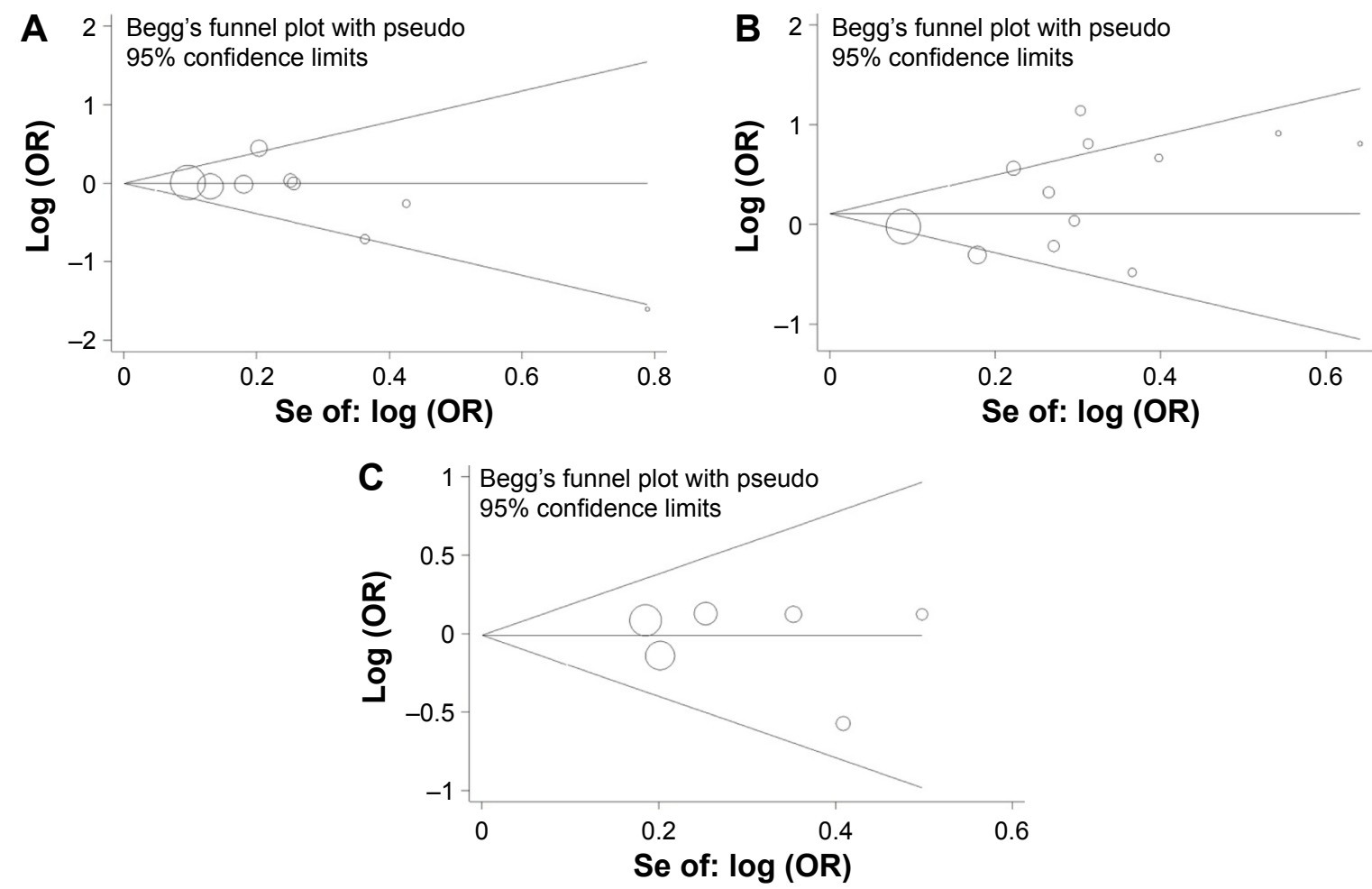

Figure 4 Begg's funnel plots for the Exol polymorphisms and the risk of cancer for the publication bias test.

Notes: Each point represents a separate study for the indicated association. Log (OR); natural logarithm of OR. The horizontal line indicates the effect size. (A) Pro757Leu polymorphism; (B) Glu589Lys polymorphism; (C) Glu670Gly polymorphism.

Abbreviation: OR, odds ratio. 
increased. Second, the studies included in this meta-analysis were satisfactory and met the inclusion criteria.

In conclusion, the results from this meta-analysis suggest that the Exo1 Pro757Leu polymorphism contributes to reduced cancer susceptibility, especially in the Asian population, hospital-based studies, and colorectal cancer. However, the Glu589Lys polymorphism was found to be statistically associated with an increased cancer risk in the Asian population, smokers, and hospital-based studies. In addition, no evidence of an association was found between the Glu670Gly polymorphism and cancer risks. In the future, well-designed and population-based studies with larger sample sizes are needed to clarify the association between these polymorphisms and the risk of cancer.

\section{Acknowledgments}

This work was supported by the National Natural Science Foundation of China (81201565), Program of the Pearl River Young Talents of Science and Technology in Guangzhou, People's Republic of China (2013J2200042), Natural Science Foundation of Guangdong Province, People's Republic of China (2014A030313293), and Specialized Research Fund for the Doctoral Program of Higher Education of China (20124433120001). The funders had no role in study design, data collection and analysis, decision to publish, or preparation of the manuscript.

\section{Disclosure}

The authors report no conflicts of interest in this work.

\section{References}

1. Pharoah PD, Dunning AM, Ponder BA, Easton DF. Association studies for finding cancer-susceptibility genetic variants. Nat Rev Cancer. 2004;4(11):850-860.

2. Siegel R, Ma J, Zou Z, Jemal A. Cancer statistics, 2014. CA Cancer J Clin. 2014;64(1):9-29.

3. Wood RD, Mitchell M, Sgouros J, Lindahl T. Human DNA repair genes. Science (New York, NY). 2001;291(5507):1284-1289.

4. Parsons JL, Dianov GL. Co-ordination of base excision repair and genome stability. DNA Repair. 2013;12(5):326-333.

5. Li WQ, Hu N, Hyland PL, et al. Genetic variants in DNA repair pathway genes and risk of esophageal squamous cell carcinoma and gastric adenocarcinoma in a Chinese population. Carcinogenesis. 2013; 34(7):1536-1542.

6. Tishkoff DX, Amin NS, Viars CS, Arden KC, Kolodner RD. Identification of a human gene encoding a homologue of Saccharomyces cerevisiae EXO1, an exonuclease implicated in mismatch repair and recombination. Cancer Res. 1998;58(22):5027-5031.

7. Tran PT, Erdeniz N, Symington LS, Liskay RM. EXO1-A multi-tasking eukaryotic nuclease. DNA Repair. 2004;3(12):1549-1559.

8. Orans J, McSweeney EA, Iyer RR, et al. Structures of human exonuclease 1 DNA complexes suggest a unified mechanism for nuclease family. Cell. 2011;145(2):212-223.

9. Keijzers G, Bohr VA, Juel Rasmussen L. Human exonuclease 1 (EXO1) activity characterization and its function on FLAP structures. Biosci Rep. Epub April 25, 2015.
10. Tishkoff DX, Boerger AL, Bertrand P, et al. Identification and characterization of Saccharomyces cerevisiae EXO1, a gene encoding an exonuclease that interacts with MSH2. Proc Natl Acad Sci US A. 1997; 94(14):7487-7492.

11. Jager AC, Rasmussen M, Bisgaard HC, Singh KK, Nielsen FC, Rasmussen LJ. HNPCC mutations in the human DNA mismatch repair gene hMLH1 influence assembly of hMutLalpha and hMLH1-hEXO1 complexes. Oncogene. 2001;20(27):3590-3595.

12. Schmutte C, Sadoff MM, Shim KS, Acharya S, Fishel R. The interaction of DNA mismatch repair proteins with human exonuclease I. J Biol Chem. 2001;276(35):33011-33018.

13. Wu Y, Berends MJ, Post JG, et al. Germline mutations of EXO1 gene in patients with hereditary nonpolyposis colorectal cancer (HNPCC) and atypical HNPCC forms. Gastroenterology. 2001;120(7):1580-1587.

14. Bregenhorn S, Jiricny J. Biochemical characterization of a cancerassociated E109K missense variant of human exonuclease 1. Nucleic Acids Res. 2014;42(11):7096-7103.

15. Yamamoto H, Hanafusa H, Ouchida M, et al. Single nucleotide polymorphisms in the EXO1 gene and risk of colorectal cancer in a Japanese population. Carcinogenesis. 2005;26(2):411-416.

16. Zienolddiny S, Campa D, Lind H, et al. Polymorphisms of DNA repair genes and risk of non-small cell lung cancer. Carcinogenesis. 2006;27(3): 560-567.

17. Kim JC, Roh SA, Yoon YS, Kim HC, Park IJ. MLH3 and EXO1 alterations in familial colorectal cancer patients not fulfilling Amsterdam criteria. Cancer Genet Cytogenet. 2007;176(2):172-174.

18. Chang JS, Yeh RF, Wiencke JK, et al. Pathway analysis of singlenucleotide polymorphisms potentially associated with glioblastoma multiforme susceptibility using random forests. Cancer Epidemiol Biomarkers Prev. 2008;17(6):1368-1373.

19. Jin $\mathrm{G}$, Wang $\mathrm{H}, \mathrm{Hu} \mathrm{Z}$, et al. Potentially functional polymorphisms of EXO1 and risk of lung cancer in a Chinese population: a case-control analysis. Lung Cancer. 2008;60(3):340-346.

20. Bau DT, Wang HC, Liu CS, et al. Single-nucleotide polymorphism of the Exol gene: association with gastric cancer susceptibility and interaction with smoking in Taiwan. Chin J Physiol. 2009;52(6):411-418.

21. Hsu NY, Wang HC, Wang CH, et al. Lung cancer susceptibility and genetic polymorphisms of Exo1 gene in Taiwan. Anticancer Res. 2009; 29(2):725-730.

22. Tsai MH, Tseng HC, Liu CS, et al. Interaction of Exol genotypes and smoking habit in oral cancer in Taiwan. Oral Oncol. 2009;45(9): e90-e94.

23. Wang HC, Chiu CF, Tsai RY, et al. Association of genetic polymorphisms of EXO1 gene with risk of breast cancer in Taiwan. Anticancer Res. 2009;29(10):3897-3901.

24. Wang SS, Bratti MC, Rodriguez AC, et al. Common variants in immune and DNA repair genes and risk for human papillomavirus persistence and progression to cervical cancer. J Infect Dis. 2009;199(1): 20-30.

25. Haghighi MM, Taleghani MY, Mohebbi SR, et al. Impact of EXO1 polymorphism in susceptibility to colorectal cancer. Genet Test Mol Biomarkers. 2010;14(5):649-652.

26. Ibarrola-Villava M, Pena-Chilet M, Fernandez LP, et al. Genetic polymorphisms in DNA repair and oxidative stress pathways associated with malignant melanoma susceptibility. Eur J Cancer. 2011;47(17): 2618-2625.

27. Bayram S, Akkiz H, Bekar A, Akgollu E, Yildirim S. The significance of Exonuclease $1 \mathrm{~K} 589 \mathrm{E}$ polymorphism on hepatocellular carcinoma susceptibility in the Turkish population: a case-control study. Mol Biol Rep. 2012;39(5):5943-5951.

28. Luo X, Hong XS, Xiong XD, Zeng LQ, Lim CE. A single nucleotide polymorphism in EXO1 gene is associated with cervical cancer susceptibility in Chinese patients. Int J Gynecol Cancer. 2012;22(2): 220-225.

29. Kabzinski J, Przybylowska K, Mik M, et al. Association of polymorphism of Lys589Glu Exo1 gene with the risk of colorectal cancer in the Polish population. Polski Przeglad Chirurgiczny. 2014;86(8):370-373. 
30. Tang H, Wei P, Duell EJ, et al. Axonal guidance signaling pathway interacting with smoking in modifying the risk of pancreatic cancer: a gene- and pathway-based interaction analysis of GWAS data. Carcinogenesis. 2014;35(5):1039-1045.

31. Breslow NE, Day NE. Statistical methods in cancer research. Volume II - The design and analysis of cohort studies. IARC Sci Publ. 1987;82:1-406.

32. Lau J, Ioannidis JP, Schmid CH. Quantitative synthesis in systematic reviews. Ann Intern Med. 1997;127(9):820-826.

33. Higgins JP, Thompson SG, Deeks JJ, Altman DG. Measuring inconsistency in meta-analyses. BMJ. 2003;327(7414):557-560.

34. DerSimonian R, Laird N. Meta-analysis in clinical trials. Controlled Clin Trials. 1986;7(3):177-188.

35. Mantel N, Haenszel W. Statistical aspects of the analysis of data from retrospective studies of disease. J Natl Cancer Inst. 959;22(4):719-748.

36. Whitehead A, Whitehead J. A general parametric approach to the meta-analysis of randomized clinical trials. Stat Med. 1991;10(11): 1665-1677.
37. Egger M, Davey Smith G, Schneider M, Minder C. Bias in meta-analysis detected by a simple, graphical test. BMJ. 1997;315(7109):629-634.

38. Yoshiya G, Takahata $T$, Hanada N, et al. Influence of cancer-related gene polymorphisms on clinicopathological features in colorectal cancer. J Gastroenterol Hepatol. 2008;23(6):948-953.

39. Huang Y, Han S, Li Y, Mao Y, Xie Y. Different roles of MTHFR C677T and A1298C polymorphisms in colorectal adenoma and colorectal cancer: a meta-analysis. J Hum Genet. 2007;52(1):73-85.

40. Gu D, Wang M, Wang M, Zhang Z, Chen J. The DNA repair gene APE1 T1349G polymorphism and cancer risk: a meta-analysis of 27 case-control studies. Mutagenesis. 2009;24(6):507-512.

41. Bayram S. The exonuclease 1 Glu589Lys gene polymorphism and cancer susceptibility: evidence based on a meta-analysis. Asian Pac $J$ Cancer Prev. 2014;15(6):2571-2576.

42. Duan F, Song C, Dai L, Cui S, Zhang X, Zhao X. The significance of Exo1 K589E polymorphism on cancer susceptibility: evidence based on a meta-analysis. PloS One. 2014;9(5):e96764.
OncoTargets and Therapy

\section{Publish your work in this journal}

OncoTargets and Therapy is an international, peer-reviewed, open access journal focusing on the pathological basis of all cancers, potential targets for therapy and treatment protocols employed to improve the management of cancer patients. The journal also focuses on the impact of management programs and new therapeutic agents and protocols on

\section{Dovepress}

patient perspectives such as quality of life, adherence and satisfaction The manuscript management system is completely online and includes a very quick and fair peer-review system, which is all easy to use. Visit http://www.dovepress.com/testimonials.php to read real quotes from published authors. 